\title{
Widely Invasive Thymoma
}

National Cancer Institute

\section{Source}

National Cancer Institute. Widely Invasive Thymoma. NCI Thesaurus. Code C45700.

A thymoma that spreads by direct extension into adjacent tissues (lung, pericardium, or

large vessels). This type of thymoma usually appears invasive at the time of excision. 